\title{
Temporal variability of the estuarine macrofauna of the Patos Lagoon, Brazil
}

\author{
Variabilidad temporal de la macrofauna estuarina de la Laguna de los Patos, Brasil \\ Leonardo C. Rosa ${ }^{1,2}$ and Carlos E. Bemvenuti ${ }^{2}$ \\ Pós-Graduação em Oceanografia Biológica - FURG ${ }^{1}$ \\ Laboratório de Ecologia de Invertebrados Bentônicos. Departamento de Oceanografia ${ }^{2}$ \\ Fundação Universidade Federal do Rio Grande (FURG). Caixa Postal 474, 96201-900, Rio Grande, RS, Brasil \\ cielcr@furg.br
}

Resumen.- La variabilidad temporal de la densidad de la macrofauna y su relación con las propiedades del agua y sedimento fue estudiada a través de muestreos mensuales en una ensenada estuarina de la Laguna de los Patos, Brasil, de enero a diciembre de 2001. Las características del agua y del sedimento mostraron un nítido patrón estacional. Los mayores valores de salinidad y temperatura del agua se observaron en los meses de verano, mientras que un aumento de las fracciones finas en el sedimento ocurrió durante el invierno. Durante el estudio fueron recolectadas 18 especies, con un total de 38.827 organismos. El bivalvo Erodona mactroides, el tanaidaceo Kalliapseudes schübartii, los poliquetos Heteromastus similis y Nephtys fluviatilis y el gasterópodo Heleobia australis fueron los organismos dominantes, correspondiendo juntos, al 90\% de la abundancia total. La macrofauna también mostró un patrón estacional de distribución, con las mayores densidades registradas durante los meses de verano (enero = 62.205 ind. $\mathrm{m}^{-2}$ ) y las menores en invierno (julio $=9.410$ ind. $\mathrm{m}^{-2}$ ). Este patrón es resultante del proceso reproductivo de las especies, el cual comienza con el aumento de la temperatura a partir de fines de primavera. Las bajas densidades en el invierno están relacionadas con el efecto de una fuerte depredación sobre estos organismos asociada con la ausencia de reclutamientos efectivos en los meses fríos. Las alteraciones sedimentarias también pueden haber contribuido a la reducción de la densidad de la macrofauna durante el invierno.

Palabras clave: Bentos, fondos blandos, estuario, Océano Atlántico suroeste

\begin{abstract}
Temporal variability of the macrofauna density and its relationship with water and sediments characteristics were studied through monthly sampling at an estuarine embayment of the Patos Lagoon, Brazil from January to December 2001. Both, water and sediments characteristics showed distinct seasonal patterns. High salinity and water temperature values were registered in summer months. Increase of fine fractions in the sediments occurred in cold months. A total of 38,827 individuals represented by 18 species were collected during the study period. The bivalve Erodona mactroides, the tanaid Kalliapseudes schübartii, the polychaetes Heteromastus similis and Nephtys fluviatilis, and the gastropod Heleobia australis were the dominant organisms, accounting for more than $90 \%$ of total macrofauna. The macrofauna also showed a seasonal pattern, with the highest density found in summer (January $=62,205$ ind. $\mathrm{m}^{-2}$ ) and the lowest one in winter (July $=9,410$ ind. $\mathrm{m}^{-2}$ ). This pattern results from the species reproductive process, which was strongly correlated to the increase of water temperature at the end of spring. The low macrofauna densities in winter are related to a high predation during summer along with the absence of effective recruitment in cold months. Furthermore, sedimentary proprieties changes due to natural climatic disturbances could also be important factors controlling the estuarine macrofauna of the Patos Lagoon by increasing mortality rates.
\end{abstract}

Key words: Benthos, shallow water, estuary, southwest Atlantic Ocean

\section{Introduction}

The analysis of macrofauna community structure has been an important tool in environmental monitoring programs (Canfield et al. 1994, Clarke \& Warwick
1994, Weisberg et al. 1997). However, the lack of knowledge about temporal variability of macrofauna is the major methodological limitation for environmental diagnose, which makes it difficult to distinguish between natural variability and eventual macrofauna response to human-produced impacts (Morrisey et al. 
1992, Clarke \& Warwick 1994). This problem is aggravated in estuarine-lagoons systems, which are considered naturally stressed environments (Wilson \& Jeffrey 1994) due to their high variability and low previsibility of environmental conditions (Kennish 1990).

The Patos Lagoon is the largest choked lagoon in the world (Kjerfve 1986). The choked lagoon characteristics and the negligible tidal amplitude ( $0.5 \mathrm{~m}$ of tidal range) make physicochemical parameters in the Patos Lagoon estuary largely dependent on wind and rainfall (Costa et al. 1998).

In contrast to subtidal estuarine habitats (Bemvenuti et al. 1992, Bemvenuti \& Netto 1998), information about temporal variability of macrofauna in shallow water areas of the Patos Lagoon is scarce. Thus, in this work the temporal distribution pattern of macrofauna and its relationship with variability of water and sediment characteristics were studied in a shallow water region of the Patos Lagoon estuary.

\section{Material and Methods}

The study was carried out in a shallow water embayment (ca. $0.8 \mathrm{~m}$ of depth) located near the east margin of Pombas Island (Fig. 1). In this region, six sites (distant $90 \mathrm{~m}$ each other) were established over the greatest linear dimension referred to south-north direction of the island, and were monthly sampled from January to December 2001.

At each site, three macrofauna sub-samples were taken using a corer tube $\left(0.008 \mathrm{~m}^{2}\right.$ area, $20 \mathrm{~cm}$ depth). Biological samples were sieved in situ through a 0.3 $\mathrm{mm}$ mesh size, fixed in 4\% buffered formaldehyde and vital stained with Rose Bengal. In the laboratory, organisms were sorted under a stereo microscope, counted and preserved in $70 \%$ ethanol. Density of benthic invertebrates was expressed as number of individuals per $\mathrm{m}^{2}$.

Additional samples were also taken to determine sediment characteristics. Granulometry data were obtained through sieving and pipetting analysis (Suguio 1973). Dried samples were combusted at $550^{\circ} \mathrm{C}$ for 60 min to determine organic content through weight loss (Walkley \& Black 1934). Water temperature and salinity data were obtained from database of the Coastal
Vegetation Ecology Laboratory (Dept. Oceanography FURG).

Data were subjected to multivariate statistical analysis. Environmental data were ordinated using a correlation-based principal component analysis (PCA). Square root transformed biological data were ordinated by non-metric multidimensional scaling ordination (MDS) using the Bray-Curtis similarity index (Clarke 1993).

Relationships between macrofauna structure and environmental variables at sampling periods were analysed with canonical correspondence analysis (CCA) (ter Braak 1986). In the CCA, biological data were square root transformed, and species with relative abundance lower that 5\% were not included in analyses. Environmental variables were manually selected and included in the analyses after testing its significance through the Monte Carlo permutation test.

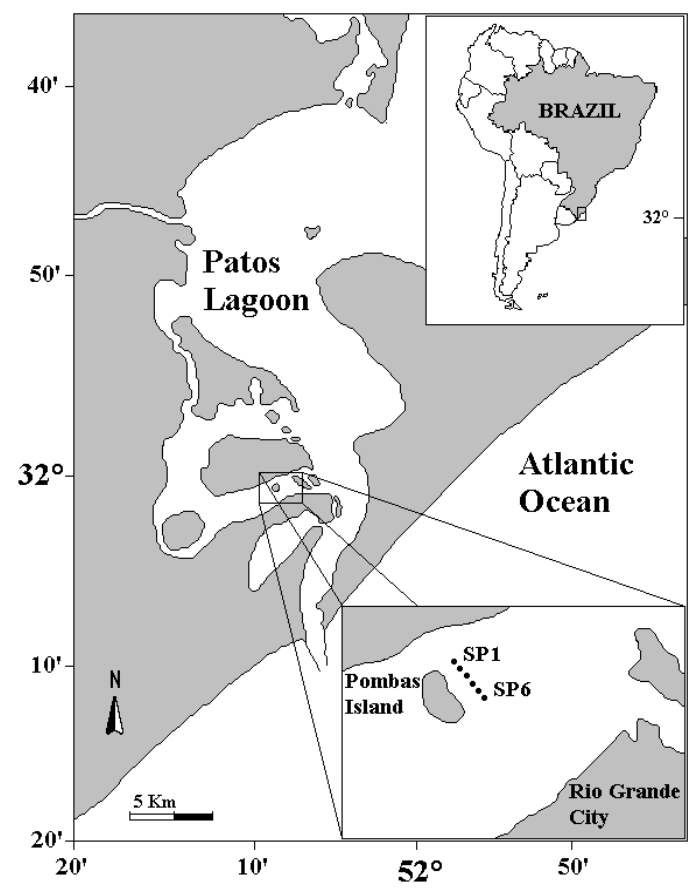

Figure 1

Map of the estuarine region of the Patos Lagoon indicating the study area in detail. SP = Sampling points

Mapa de la región estuarina de la Laguna de los Patos mostrando en detalle el área de estudio. SP = Puntos de muestreo 


\section{Results}

Water temperature showed a clear seasonal pattern (Fig. 2a), with the highest values registered in summer (January to March), and the lowest in winter (JuneAugust). Water salinity had a less marked temporal pattern, with mean values ranging from 0.5 to $10.5 \mathrm{psu}$ (Fig. 2b), however, the highest monthly mean values were registered at early autumn (April) and early summer (January).
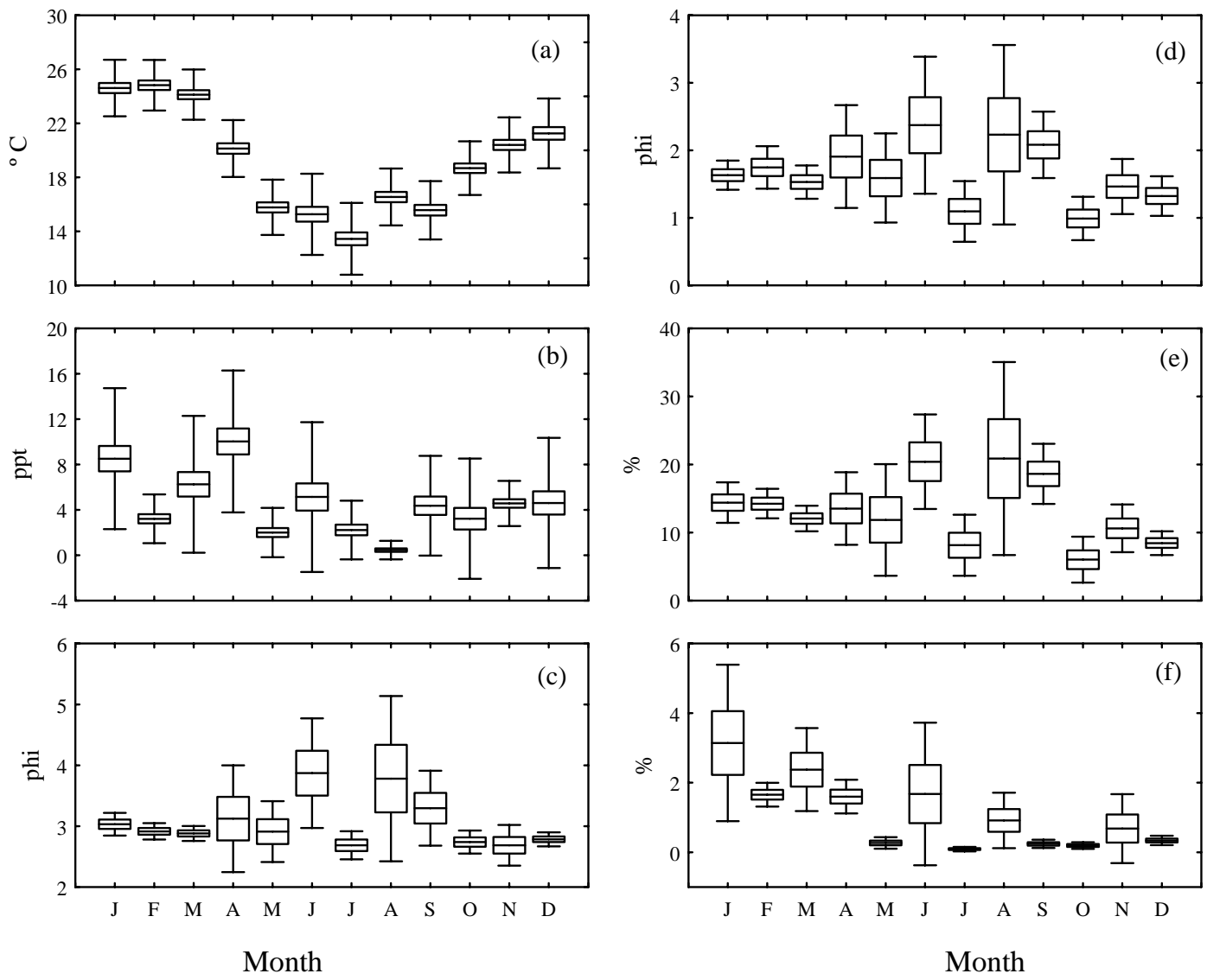

Figure 2

Temporal variability of: (a) water temperature, (b) salinity, (c) mean grain size, (d) sorting, (e) fine fractions and, (f) organic matter content in the sediment in Laguna de los Patos. Mean value (line), standard error (box) and deviation (whisker)

Variación temporal de: (a) temperatura del agua, (b) salinidad, (c) tamaño medio del grano, (d) grado del selección, (e) porcentaje de las fracciones finas y, (f) contenido de materia orgánica del sedimento en la Laguna de los Patos. Valor medio (línea), error (caja) y desviación (barra) 


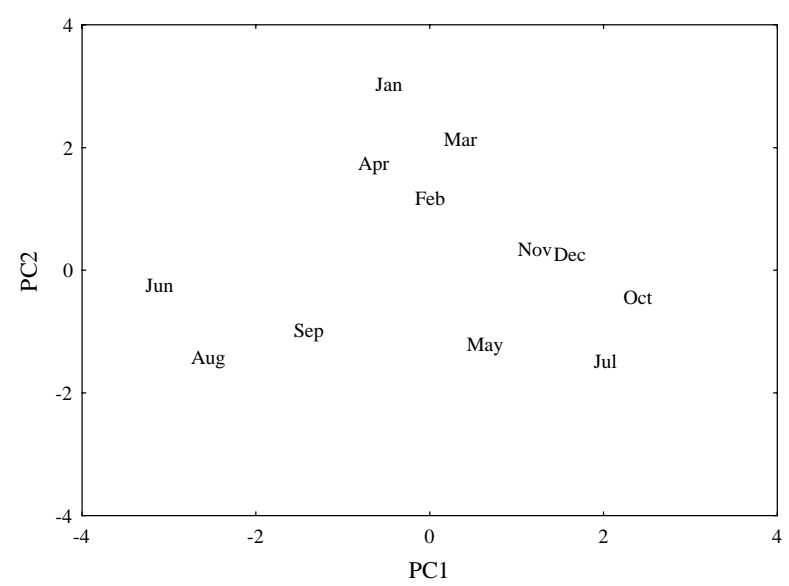

Figure 3

\section{PCA diagram on environmental data}

Diagrama del PCA sobre los datos ambientales

Ordination by PCA (Fig. 3) of environmental data showed also a clear seasonal pattern. The first two components explained $87.5 \%$ of the data variance (PC 1 $=50.3 \%$ and PC $2=37.2 \%$ ). On component 1 , high negative values were associated to sediment propieties (i.e., mean grain size, sorting and fines fractions). Positive values on second component were associated to water temperature and salinity, and organic matter content (Fig. 3).

During the study period a total of 38,827 individuals, represented by 18 species were collected. The most abundant organisms were the bivalve Erodona mactroides, the tanaid Kalliapseudes schübartii, the isopod Uromunna peterseni, the gastropod Heleobia australis and the polychaetes Heteromastus similis and Nephtys fluviatilis, accounting for more than $95 \%$ of total macrofauna (Table 1). All dominant species showed a clear seasonal pattern with higher densities during summer (Fig. 4). The only exception was the polychaete $H$. similis, which showed little temporal variation along the entire study period (Fig. 4).

MDS ordination (Fig. 5) also showed a clear seasonal pattern in macrofauna community structure; months with higher macrofauna densities (JanuaryFebruary) were clustered in the right side of this diagram, while months with low macrofauna densities, in the left (June-October).

In the CCA analysis, the first axis (eigenvalue = 0.031 ) alone modeled $65.3 \%$ of total explained variance, showing a higher species-environment correlation (Table 2). Water temperature, salinity and organic matter content were strongly correlated with the first axis, while mean grain size, sorting and fines fractions were correlated with the second axis (Table 2).

From CCA diagrams (Fig. 6), we can infer that the first axis corresponds mainly to seasonal pattern of water column propieties, in which months with high temperature and salinity were clustered at the left side of the ordination plot, and those showing lower values cluster at the right side. The second axis contrasts months with lower mean grain size and sorting, and with higher fines fractions in the sediments (upper side) with months when mean grain size and sorting were higher and fines fractions were lower in the sediment (Fig. 6).

\section{Table 1}

Total of individuals $(\mathrm{N})$ and relative abundance $(\%)$ of each species collected during the study period

Total de individuos (N) y abundancia relativa (\%) de cada especie recolectada durante el período de estudio

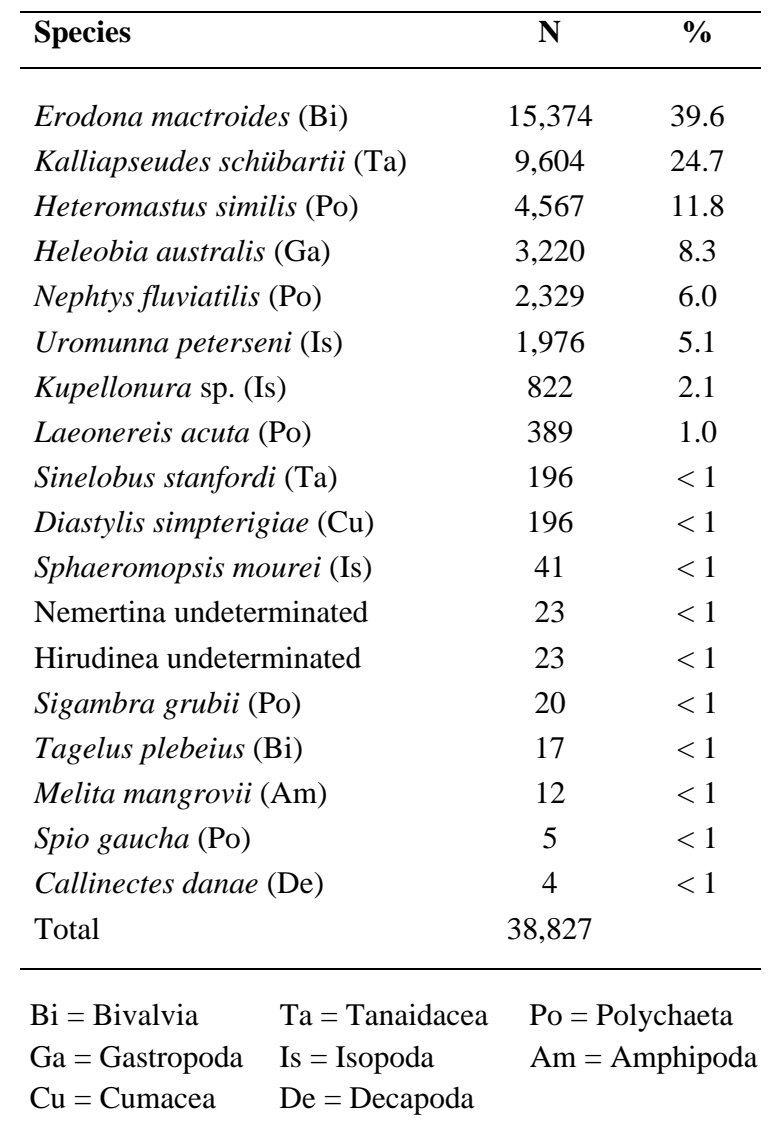



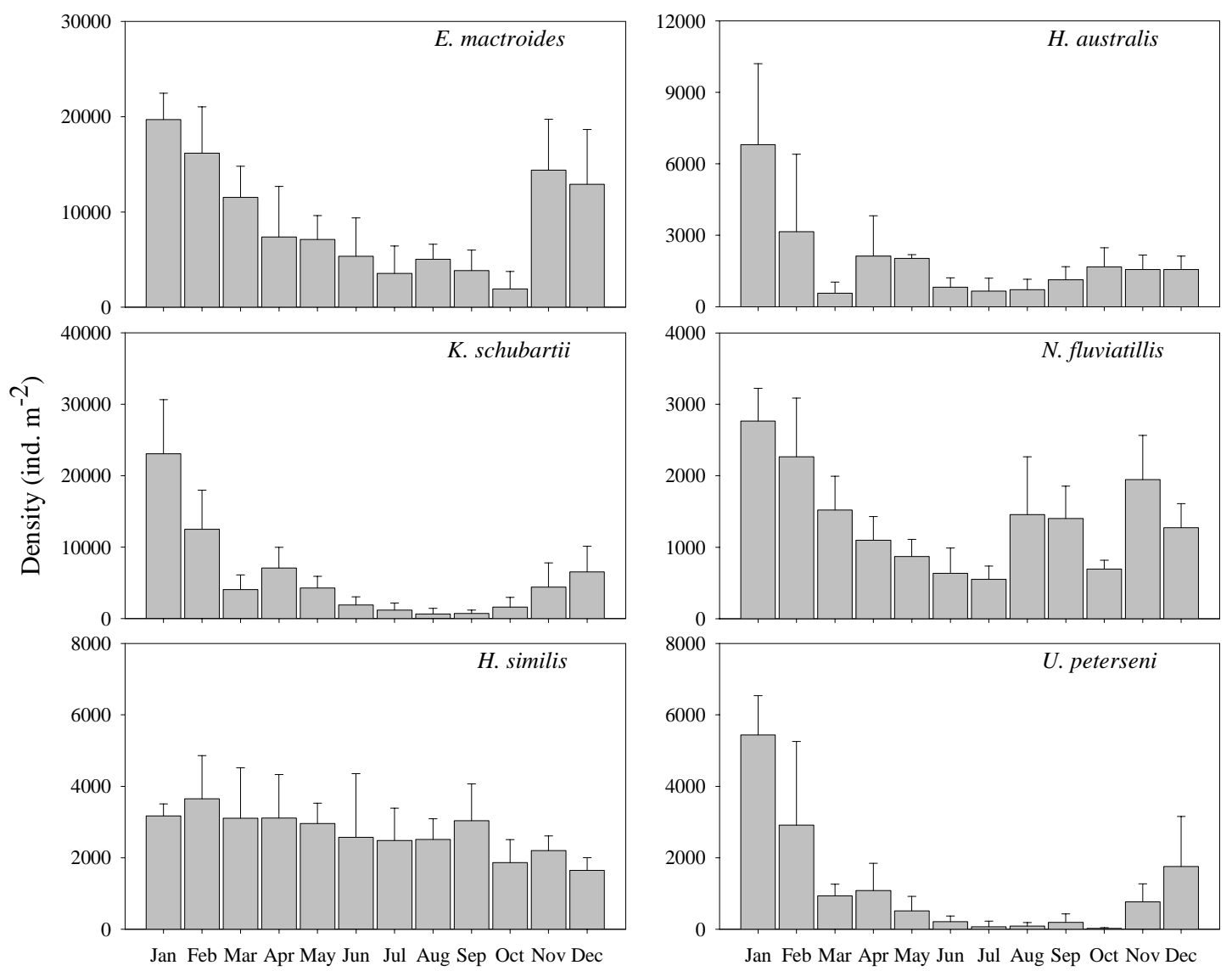

Month

Figure 4

Mean densities of the dominant macrofaunal organisms registered in Laguna de los Patos during the study period

Densidades medias de los organismos macrofaunales dominantes en la Laguna de los Patos, durante el período de estudio

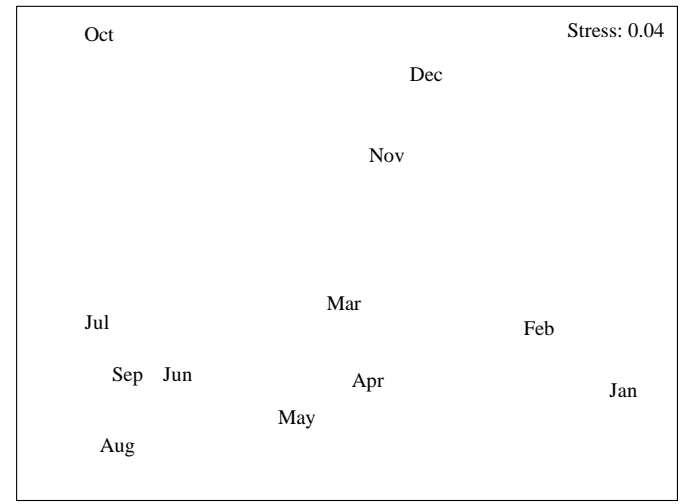

Figure 5

MDS ordination on square root transformed biological data

Ordenación del MDS sobre los datos biológicos transformados por la raíz cuadrada 
Table 2

Results of CCA performed on macrofauna abundance and environmental variables

Resultados del CCA realizado sobre los datos de abundancia de la macrofauna y variables ambientales

\begin{tabular}{lcccc}
\hline AXES & 1 & 2 & 3 & 4 \\
\hline Biplot scores of environmental variables & & & & \\
Salinity & -0.646 & 0.090 & -0.411 & 0.089 \\
Water temperature & -0.955 & -0.098 & 0.272 & 0.014 \\
Organic matter content (\%) & -0.764 & 0.514 & 0.092 & 0.164 \\
Mean grain size $(\phi)$ & 0.349 & 0.660 & 0.308 & 0.081 \\
Sorting $(\phi)$ & 0.160 & 0.683 & 0.322 & -0.323 \\
Fine fractions (\%) & 0.180 & 0.726 & 0.460 & -0.222 \\
Summary statistics for ordination axes & & & & \\
Eigenvalues & & & & \\
Species-Environment correlation & 0.031 & 0.012 & 0.003 & 0.001 \\
Cumulative percentage variance (\%) of: & 0.869 & 0.945 & 0.862 & 0.485 \\
$\quad$ Species & & & & \\
$\quad$ Species- Environment relation & 42.9 & 60.1 & 63.8 & 65.8 \\
\hline
\end{tabular}

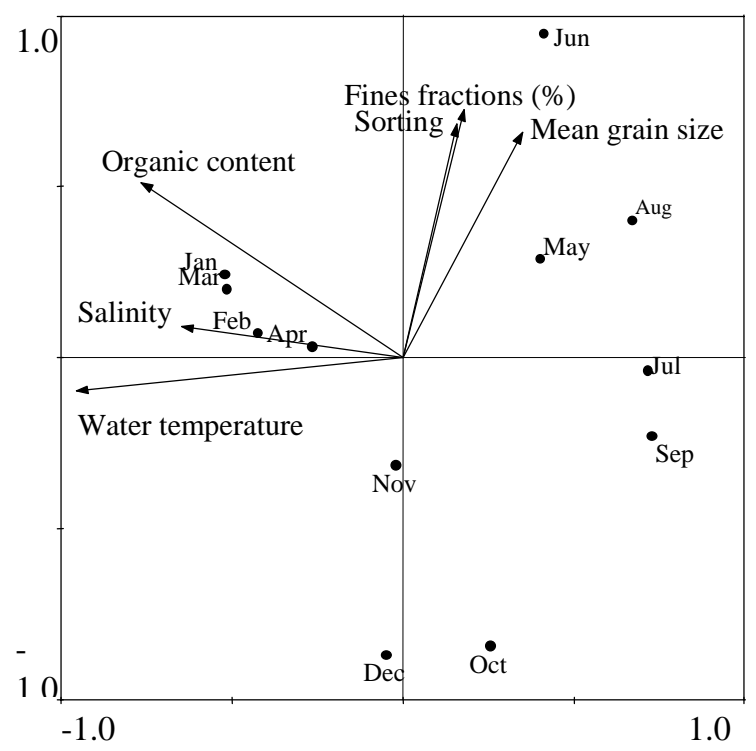

Figure 6

\section{CCA ordination plot}

Diagrama de la ordenación del CCA

\section{Discussion}

Both, water column and sediment propieties showed clear seasonal patterns, characteristic of subtropical regions. In Patos Lagoon, summer months with higher temperatures and lower precipitation rates favor marine water intrusion into the estuarine region resulting in higher salinity values, as observed in this study. In contrast, high precipitation during winter months increase runoff and lower salinity values are observed.

Climatic perturbations such as cold fronts are also frequently observed in the region during winter. During these situations, the increase of wind intensity changes the local hydrodynamics favoring the resuspension, transport and deposition of sediment in the whole estuarine region (Calliari 1980). The winter increase of fines fractions and consequent reduction of both grain size and sorting in sediment are probably related to sedimentary deposition processes resultants of these climatic perturbations.

Estuarine macrofauna also showed a clear seasonal pattern, strongly correlated with the temporal variability of both, water column and sediment characteristics. The higher macrobenthic densities observed in summer are related to recruitment processes, which in turn is influenced by the increase of temperature and salinity (Bemvenuti 1987, 1997). This temporal pattern has also been registered in other temperate regions like Chesapeake Bay, USA (Holland 1985), Rio Queule Estuary, Chile (Quijón \& Jaramillo 1993) and Samborombon Bay, Argentina (Ieno \& Bastida 1998). 
With the temperature increasing in late spring and early summer, the reproductive activity of macrofaunal species increases, resulting in dense recruitment in the estuarine inlets of the region (Bemvenuti 1987, 1997b). However, during the recruitment period these species are subjected to strong populational control by epifaunal macropredators (Bemvenuti 1987, 1997c). Most macrofauna species are typical food items for marine organisms like the fish Micropogonias furnieri, the blue crab Callinectes sapidus and the pink shrimp Farfantepenaeus paulensis (Bemvenuti 1987, Kapusta \& Bemvenuti 1998), which use the estuarine shallow waters as nursery areas.

On another hand, the strong predation pressure during the warm season and the absence of effective recruitment rates during cold months resulted in the lower macrofauna densities observed in winter. However, low reproductive rates during the cold months are somewhat compensated by the absence of most epibenthic predators (Bemvenuti 1987, 1997a).

Furthermore, climatic perturbations such as cold fronts displacement may also have contributed to lower macrofauna densities in winter. Sedimentary changes resultant of such climatic disturbances could have significant effects on macrofauna, especially on sedentary and superficial burrowing organisms (Grant 1983, Posey et al. 1996). In the Patos Lagoon estuary, previous studies had already registered high mortality rates of macrofaunal organisms (e.g., the bivalve $E$. mactroides), after ressuspension and deposition processes due to cold fronts displacements (Bemvenuti et al. 1978, Bemvenuti 1997b, Geraldi 2002). However, the effects of these climatic disturbances on macrofauna are still understudied.

Among the dominant species, the polychaete Heteromastus similis was the only one that did not show a clear seasonal pattern. This temporal pattern had already been registered for Patos Lagoon (Bemvenuti 1987, 1988, 1994), as well as for other estuaries in South Atlantic (e.g., Mar Chiquita Estuary and Samborombon Bay (Ieno \& Elias 1995 and Ieno \& Bastida 1998, respectively). Studies on temporal variability of this polychaete had shown the presence of juveniles along the entire year, suggesting the absence of a seasonal recruitment pattern (Ieno \& Bastida 1998).

Along with the absence of a seasonal recruitment pattern, low predation on these polychaetes probably contributed to the small temporal variability observed. Field experiments carried out in the Patos Lagoon estuary had evidenced that $H$. similis is little affected by predators' exclusion (Bemvenuti 1987, 1988, 1994). Additionally, the low frequency of $H$. similis individuals in the stomach content of the zoobenthophagic predators (Capitoli 1982) corroborates the low predation effects on this polychaete.

$H$. similis is a sub-superficial deposit feeder inhabiting deep galleries into the sediment (Netto \& Lana 1995, Bemvenuti 1997a). Its burrowing capacity has been pointed as the main escape strategy from predation, since most epifaunal predators act mainly on superficial sediment layer (Virstein 1977, Holland et al. 1980, Bemvenuti 1988).

The subsuperficial distribution could also contribute to low susceptibility of this polychaete to superficial sediment disturbance due climatic alterations such as cold fronts displacements. Field experiments in the euhaline region of the Paranaguá Bay (Netto \& Lana 1994) showed that $H$. similis densities after artificial sediment disturbances return to initial levels in two days. In this way, the absence of a seasonal recruitment pattern and the low mortality rates allowed by subsuperficial habits may be the main factors responsible for the low temporal variability observed for $H$. similis density in this study.

Estuarine macrofauna showed a marked seasonal pattern, strongly correlated to temporal change of water column and sedimentary propieties. During summer, the highest macrofauna densities are related to recruitment processes strongly correlated to water temperature increases. The highest predation effect during summer along with the absence of effective recruitment in warm months resulted in the low macrofauna densities observed during winter. Furthermore, sedimentary propieties changes due to natural climatic disturbances might also be an important controlling factor of the estuarine macrofauna of the Patos Lagoon by increasing mortality rates.

\section{Acknowledgments}

The authors would like to thank Ricardo Queiroz for his comments and the english revision. We also thank the anonymous referees for their helpful comments. This study received financial support from the Brazilian Long Term Ecological Research (CNPq - PELD; Proc. 
\# 520188/98-5) and, L. C. Rosa was supported by a scholarship from the Coordenadoria de Aperfeiçoamento de Pessoal de Nível Superior (CAPES).

\section{Literature cited}

Bemvenuti CE. 1987. Predation effects on a benthic community in estuarine soft sediments. Atlântica 9: 5-32.

Bemvenuti CE. 1988. Impacto da predação sobre Heteromasthus similis Southern, 1921 e Nephtys fluviatilis Monro, 1937 (Annelida, Polychaeta), em fundos moles estuarinos. Atlântica 10: 85-102.

Bemvenuti CE. 1994. O poliqueta Nephtys fluviatilis Monro,1937 como predador da infauna na comunidade de fundos moles. Atlântica 16: 87-98.

Bemvenuti CE. 1997a. Benthic Invertebrates. In: Seeliger U, C Odebrecht \& JP Castello (eds). Subtropical convergence environments: the coast and sea in the southwestern Atlantic, pp. 43-46. Springer-Verlag, Berlin.

Bemvenuti CE. 1997b. Unvegeted intertidal flats and subtidal bottoms. In: Seeliger U, C Odebrecht \& JP Castello (eds). Subtropical convergence environments: the coast and sea in the southwestern Atlantic, pp. 78-82. Springer-Verlag, Berlin.

Bemvenuti CE. 1997c. Trophic structure. In: Seeliger U, C Odebrecht \& JP Castello (eds). Subtropical convergence environments: the coast and sea in the southwestern Atlantic, p. 70-73. Springer-Verlag, Berlin.

Bemvenuti CE, RR Capitoli \& NM Gianuca. 1978. Estudos de ecologia bentônica na região estuarial da Lagoa dos Patos. II - Distribuição quantitativa do macrobentos infralitoral. Atlântica 3: 23-32.

Calliari LJ. 1980. Aspectos sedimentológicos e ambientais da região sul da Lagoa dos Patos. Tese de Geociências, Universidade Federal do Rio Grande do Sul, Porto Alegre, 190 pp.

Canfield TJ, NE Kemble, WG Brumnaugh, FJ Dwyer, CG Ingersoll \& FJ Fairchild. 1994. Use of benthic invertebrates community structure and the sediment quality triad to evaluate metal-contaminated sediment in the upper Clark Fork River, Montana. Environmental Toxicology and Chemistry 13: 1999-2012.

Capitoli SN. 1982. Benthic-demersal interspecific trophic relationship in the mixohaline area of the Patos Lagoon, Brazil. Atlântica 5: 22-23.
Clarke KR \& RM Warwick. 1994. Changes in marine communities: an approach to statistical analyses and interpretation, 144 pp. Natural Environment Research Council, London.

D'Incao F. 1991. Pesca e biologia de Penaeus paulensis na Lagoa dos Patos, RS. Atlântica 13: 159-169.

Folk R \& WC Ward. 1957. Brazos River bar: a study in the significance of grain size parameters. Journal of Sedimentary Petrology 27: 3-26.

Geraldi RM. 2002. Distribuição, espacial, recrutamento, crescimento e mortalidade de Erodona mactroides Bosc, 1802 (Mollusca, Pelecypoda) na Lagoa dos Patos, RS, Brasil. Tese de Oceanografia Biológica, Universidade Federal do Rio Grande, Rio Grande, 166 pp.

Grant J. 1983. The relative magnitude of biological and physical sediment reworking in an intertidal community. Journal of Marine Research 41: 673-689.

Holland AF. 1985. Long-term variation of macrobenthos in an mesohaline region of Chesapeake Bay. Estuaries 8: 93113.

Holland AF, NK Mountford, MH Hiegel, KR Kaumeyer \& JA Mihursky. 1980. Influence of predation on infaunal abundance in Upper Chesapeake Bay, USA. Marine Biology 57: 221-235.

Ieno EN \& R Elias. 1995. Heteromastus similis Southern, 1921 (Polychaeta: Capitellidae) in Mar Chiquita brackish coastal lagoon, Argentina. Nerítica 9: 23-32.

Ieno EN \& RO Bastida. 1998. Spatial and temporal patterns in coastal macrobenthos of Samborombon Bay, Argentina: a case study of very low diversity. Estuaries 21: 690-699.

Kennish MJ. 1990. Ecology of estuaries: biological aspects, 279 pp. CRC Press Inc., Boca Raton.

Morrisey DJ, AJ Underwood, L Howitt \& JS Stark. 1992. Temporal variation in soft-sediment benthos. Journal of Experimental Marine Biology and Ecology 164: 233-245.

Netto SA \& PC Lana. 1994. Effects of sediment disturbance on the structure of benthic fauna in a subtropical tidal creek of southeastern Brazil. Marine Ecology Progress Series 106: 239-247.

Netto SA \& PC Lana. 1995. Zonação e estratificação da macrofauna bêntica em um banco areno-lodoso do setor euhalino de alta energia da Baía de Paranaguá (Paraná, Brasil). Iheringia Série Zoologia 79: 27-37. 
Posey MH, W Lindberg, T Alphin \& F Vose. 1996. Influence of storm disturbance on an offshore benthic community. Bulletin of Marine Science 59: 523-529.

Quijón P \& E Jaramillo. 1993. Temporal variability in the intertidal macroinfauna in the Queule River Estuary, South-central Chile. Estuarine, Coastal and Shelf Science 37: 655-667.

Suguio K. 1973. Introdução à sedimentologia, 317 pp. EDUSP, São Paulo.

ter Braak CJF. 1986. Canonical correspondence analysis: a new eigenvector technique for multivariate direct gradient analysis. Ecology 67: 1167-1179.
Virstein RW. 1977. The importance of predation by crabs and fishes on benthic infauna in Chesapeake Bay. Ecology 58: 1199-1217.

Walkley A \& IA Black. 1934. An examination of the Degtjareff method for determining soil organic matter and proposed modification of the cromic and titration method. Soil Science 37: 29-38.

Weisberg SB, JA Ranasingue, DM Dauer, LC Scaffner, RJ Diaz \& JB Frithsen. 1997. An estuarine benthic index of biotic integrity (B-IBI) for Chesapeake Bay. Estuaries 20: 149-158.

Wilson JG \& DW Jeffrey. 1994. Benthic biological pollution indices in estuaries. In: Kramer KJM (ed). Biomonitoring of coastal waters and estuaries, pp. 311-327. CRC Press Inc., Boca Raton.

Recibido el 1 de agosto de 2005 y aceptado el 16 de enero de 2006 